Research paper

\title{
Effect of inhibitors and fertigation strategies on GHG emissions, NO fluxes and yield in irrigated maize
}

\author{
Guillermo Guardia ${ }^{\mathrm{a}, *}$, Max T. Cangani ${ }^{\mathrm{b}}$, Gemma Andreu $^{\mathrm{a}}$, Alberto Sanz-Cobena ${ }^{\mathrm{a}}$, \\ Sonia García-Marco ${ }^{a}$, José Manuel Álvarez ${ }^{a}$, Jaime Recio-Huetos ${ }^{a}$, Antonio Vallejo ${ }^{a}$ \\ a ETSI Agronómica, Alimentaria y de Biosistemas (ETSIAAB), Technical University of Madrid (UPM), Ciudad Universitaria, 28040 Madrid, Spain

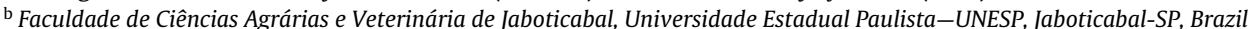

\section{A R T I C L E I N F O}

\section{Article history:}

Received 16 June 2016

Received in revised form 9 January 2017

Accepted 9 January 2017

Available online 21 January 2017

\section{Keywords:}

GHG emission

Nitric oxide emission

Nitrification inhibitor DMPSA

Urease inhibitor NBPT

Fertigation

\begin{abstract}
A B S T R A C T
Abating large losses of nitrogen $(\mathrm{N})$ oxides while maintaining or enhancing crop yield is a major goal in irrigated maize (Zea mays L) cropping areas. During two consecutive campaigns, the new nitrification inhibitor 2-(3,4-dimethyl-1H-pyrazol-1-yl) succinic acid isomeric mixture (DMPSA) applied with calcium ammonium nitrate (CAN) and the same fertilizer applied by drip-fertigation without the inhibitor, were evaluated and compared with CAN broadcast to the surface and irrigated with sprinklers. Concurrently, urea-based treatments such as urea-fertigation and the broadcast application of urea combined with sprinkler irrigation, with or without the urease inhibitor N-butyl thiophosphorictriamide (NBPT), were also assessed. Nitrous oxide $\left(\mathrm{N}_{2} \mathrm{O}\right)$ and nitric oxide (NO) fluxes, grain and biomass yield and yieldscaled $\mathrm{N}_{2} \mathrm{O}$ emissions of the different treatments were compared. Additionally, methane $\left(\mathrm{CH}_{4}\right)$ and carbon dioxide $\left(\mathrm{CO}_{2}\right)$ fluxes were measured. On average, fertigation treatments led to a mitigation of $\mathrm{N}_{2} \mathrm{O}$ emissions with respect to sprinkler irrigation by $80 \%$ and $78 \%$ for CAN and urea, respectively. With regards to inhibitor-based strategies, the use of DMPSA and NBPT reduced $\mathrm{N}_{2} \mathrm{O}$ losses by $58 \%$ and $51 \%$, respectively, considering the average of both maize cropping seasons. Since no differences in grain yield were observed between fertilized treatments, DMPSA and fertigation treatments gave the lowest values of yield-scaled $\mathrm{N}_{2} \mathrm{O}$ emissions, leading to reductions of $63 \%, 71 \%$ and $78 \%$ for CAN with DMPSA, urea-fertigation and CAN-fertigation, respectively, with respect to conventional management strategies (surface broadcast application and sprinkler irrigation). Low NO emissions during the first campaign masked differences between treatments, whereas during the second season, NO losses significantly decreased in the following order: conventional treatments $>$ inhibitors $>$ fertigation. Comparing conventional management practices, CAN significantly decreased emissions of $\mathrm{N}$ oxides compared with urea, but this effect was only observed in the second maize cropping season. The moisture distribution pattern in drip plots (dry and wet areas) caused a reduction of $\mathrm{CH}_{4}$ sink (only in one of the two seasons) and respiration fluxes, in comparison to sprinkler. This study shows that the use of the new nitrification inhibitor DMPSA and drip-fertigation should be promoted in irrigated maize agro-ecosystems, in order to mitigate emissions of $\mathrm{N}$ oxides without penalizing grain yield and leading to similar or enhanced biomass production.
\end{abstract}

(C) 2017 Elsevier B.V. All rights reserved.

\section{Introduction}

With production of almost $700 \mathrm{Mt}$, maize is one of the three most important crops in the world (FAO, 2014). Thus, the intensive production of maize is of major economic relevance in regions such as USA and Canada (Corn Belt), China, Mexico, Brazil, Argentina and irrigated semi-arid areas (e.g. Mediterranean regions). Due to its

\footnotetext{
* Corresponding author.

E-mail address: guillermo.guardia@upm.es (G. Guardia).
}

high water and fertilizer (particularly nitrogen, N) demand, maize cropping has a high potential to generate large $\mathrm{N}$ losses, through ammonia $\left(\mathrm{NH}_{3}\right)$ volatilization, nitrate $\left(\mathrm{NO}_{3}{ }^{-}\right)$leaching and $\mathrm{N}$ oxides emissions (Rimski-Korsakov et al., 2012; Huang et al., 2015; Abalos et al., 2016; Cayuela et al., 2016). The latter include nitrous oxide $\left(\mathrm{N}_{2} \mathrm{O}\right)$, a harmful greenhouse gas (GHG) (Myhre et al., 2013) which is mainly produced through the soil microbial processes of nitrification and denitrification (Firestone and Davidson, 1989); and nitric oxide (NO), which is involved in the formation of tropospheric ozone and is mainly generated through nitrification (Skiba et al., 1997). Finding management practices that lead to lower N losses 
while maintaining yield is, therefore, crucial in maize cropping areas, to assure both economic and environmental sustainability of these agro-ecosystems.

Some potential strategies have been suggested for reducing $\mathrm{N}$ losses in maize areas. These involve: i) the substitution of synthetic fertilizers by organic ones, which has been shown to penalize crop yields (Abalos et al., 2016; Guardia et al., 2016); ii) the use of urease inhibitors (Sanz-Cobena et al., 2012); iii) the use of nitrification inhibitors (NIs) (Migliorati et al., 2014); iv) the use of water-saving irrigation strategies such as drip irrigation (Guardia et al., 2016) and $\mathrm{v}$ ) the split application of $\mathrm{N}$ fertilization in order to improve the synchronization of $\mathrm{N}$ supply to maize demand (Quemada et al., 2013). The last two mitigation options could be combined through drip-fertigation systems, which can be technically achievable in maize areas without yield penalties (Couto et al., 2013), as well as improving weed management. Several field studies have demonstrated that drip irrigation reduces emissions $\mathrm{N}$ oxides (Sánchez-Martín et al., 2008; Sanchez-Martín et al., 2010). With regards to fertigation, Kennedy et al. (2013) reported that the integrated management of a processing tomato field (including fertigation) emitted less $\mathrm{N}_{2} \mathrm{O}$ and had greater crop yield than the conventional system (furrow irrigation and seeding fertilization) as a result of lower substrate (mineral $\mathrm{N}$ ) availability. By contrast, Vallejo et al. (2014) highlighted the potential of drip-fertigation to give higher $\mathrm{N}_{2} \mathrm{O}$ emissions when compared with basal fertilization and drip irrigation, but with low emission factors in both cases. So far, no studies have been published about the effect of drip-irrigation on losses of $\mathrm{N}$ oxides in maize cropping areas.

The use of urease inhibitors such as N-butyl thiophosphorictriamide (NBPT) is an effective strategy to mitigate $\mathrm{NH}_{3}$ volatilization (Bittman et al., 2014), but some studies have pointed out their potential for also reducing $\mathrm{N}_{2} \mathrm{O}$ (Sanz-Cobena et al., 2012) and NO losses (Abalos et al., 2012). The use of nitrification inhibitors has been described as a useful tool for enhancing $\mathrm{N}$ use efficiency and, therefore, abating N losses (Akiyama et al., 2010; Qiao et al., 2015; Gilsanz et al., 2016), which can also improve crop yields (Abalos et al., 2014a). To date, studies have mainly focused on dicyandiamide (DCD) and 3,4 dimethylpyrazol phosphate (DMPP), which have been extensively evaluated under several climatic conditions. Conversely, no studies have yet evaluated the effectiveness of new inhibitors such as 2-(3,4-dimethyl-1H-pyrazol-1-yl) succinic acid isomeric mixture (DMPSA) on abating yield-scaled $\mathrm{N}$ oxide emissions. This new inhibitor was developed to be used with basic reaction fertilizers (e.g. calcium ammonium nitrate, CAN), which cause DMPP to be unstable.

Since cost appears to be the main barrier for a broad adoption by farmers (Timilsena et al., 2015), the comparison of the mitigation potential of inhibitors and drip-fertigation, as well as the yield response, needs to be carried out. Other potential cost-effective mitigation strategies, such us changing the $\mathrm{N}$ source (e.g. replacing urea by CAN) could be of interest in maize cropping areas with large nitrification losses, such as low C-content semi-arid soils (Aguilera et al., 2013; Zhang et al., 2016).

The main objectives of this experiment were to evaluate the effect of 1) urease (NBPT) and nitrification (DMPSA) inhibitors and 2) mineral fertilizers (CAN and urea) applied by drip-fertigation; compared with conventional management (CAN and urea without inhibitors applied at dressing in sprinkler-irrigated maize) in mitigating $\mathrm{N}_{2} \mathrm{O}$ and $\mathrm{NO}$ losses. The response of crop yield and $\mathrm{N}$ uptake to these treatments was also assessed. Additionally, the modification of soil moisture content and its distribution through the soil profile as a result of different water-management systems may affect $\mathrm{CO}_{2}$ (Borken and Matzner, 2009) and $\mathrm{CH}_{4}$ fluxes (Tate, 2015), so they were also measured. Our hypothesis was that alternative management practices (inhibitors and drip-fertigation) could mitigate GHG and NO losses while enhancing crop yields.

\section{Materials and methods}

\subsection{Site description}

The study was carried out at "El Encín" field station in Madrid (latitude $40^{\circ} 32^{\prime} \mathrm{N}$, longitude $3^{\circ} 17^{\prime} \mathrm{W}$ ). The soil was a Calcic Haploxerept (Soil Survey Staff, 1992) with a sandy clay loam texture (clay, 28\%; silt, 17\%; sand, 55\%) in the upper horizon $(0-28 \mathrm{~cm}$ ) with vermiculite as a dominant clay mineral. Some relevant characteristics of the top $0-28 \mathrm{~cm}$ soil layer are as follows: total organic C, $8.1 \pm 0.3 \mathrm{~g} \mathrm{~kg}^{-1} ; \mathrm{pH}_{\mathrm{H} 2 \mathrm{O}}, 7.6$; bulk density, $1.4 \pm 0.1 \mathrm{~g} \mathrm{~cm}^{-3}$; and $\mathrm{CaCO}_{3}, 13.2 \pm 0.4 \mathrm{~g} \mathrm{~kg}^{-1}$. At the beginning of the experimental period, the $\mathrm{NH}_{4}{ }^{+}$content was $1.0 \mathrm{mg} \mathrm{NH}_{4}{ }^{+}-\mathrm{N} \mathrm{kg} \mathrm{soil}^{-1}$; the $\mathrm{NO}_{3}{ }^{-}$ content was $15.9 \mathrm{mg} \mathrm{NO}_{3}{ }^{-}-\mathrm{N} \mathrm{kg} \mathrm{soil}^{-1}$; and the dissolved organic $\mathrm{C}$ (DOC) content was $50.8 \mathrm{mg} \mathrm{C} \mathrm{kg} \mathrm{soil}{ }^{-1}$. The site has a semiarid Mediterranean climate with a dry and hot summer period, and the mean annual temperature and rainfall (over the last 10 years) in this area are $13.2^{\circ} \mathrm{C}$ and $460 \mathrm{~mm}$, respectively.

Rainfall and temperature data were obtained from a meteorological station located at the field site (CR23X micro logger, Campbell Scientific, Shepshed, UK, equipped with a Young ${ }^{\circledR}$ tipping bucket rain gauge (RM Young Company, Michigan, USA). The soil temperature was monitored using a temperature probe (SKTS 200 , Skye Instruments Ltd., Llandrindod Wells, UK) inserted $10 \mathrm{~cm}$ into the soil. The mean hourly data were stored on a data logger (DataHog, Skye Instruments Ltd., Llandrindod Wells, UK).

\subsection{Experimental design and management}

A total of 24 plots $(7 \mathrm{~m} \times 6.5 \mathrm{~m})$ were selected and arranged in a split plot design with 8 irrigation-fertilization combinations: (i) Urea-sprinkler irrigation (U-S), (ii) CAN-sprinkler irrigation (CAN-S), (iii) Urea + NBPT $\left(\right.$ UTEC $^{\circledR}$ ) with sprinkler irrigation (UIS), (iv) CAN + DMPSA with sprinkler irrigation (CAN+NI-S) (v) Urea applied by drip-fertigation (U-D), (vi) CAN applied by drip-fertigation (CAN-D), (vii) Control without any $\mathrm{N}$ fertilizer with sprinkler irrigation (C-S), (viii) and with drip irrigation (CD).

The experiment was conducted during two consecutive cropping seasons, 2014 and 2015. In both of them, a cultivator pass was performed before seeding (15th and 13th April in 2014 and 2015, respectively). Maize (Zea mays L. FAO class 600) was sown on 7th May and 17th April in 2014 and 2015, respectively, with a plant density of 7.50 plants $\mathrm{m}^{-2}$. A basal fertilization was applied on 30th April 2014 and 14th April 2015, spreading by hand $50 \mathrm{~kg} \mathrm{Pha}^{-1}$ and $150 \mathrm{~kg} \mathrm{Kha}^{-1}$ as $\mathrm{Ca}\left(\mathrm{H}_{2} \mathrm{PO}_{4}\right)_{2}$ and $\mathrm{K}_{2} \mathrm{SO}_{4}$, respectively, in all plots.

For treatments U-S, CAN-S, U-I and CAN-NI $180 \mathrm{~kg} \mathrm{~N} \mathrm{ha}^{-1}$ were spread by hand onto the surface of the plots on 17th June (both years). The fertigation in the corresponding plots (U-D and CAND) was split into two applications of $90 \mathrm{~kg} \mathrm{Nha}^{-1}$ at 6 and 10-12 pair of leaves stage ( $180 \mathrm{~kg} \mathrm{Nha}^{-1}$ in total). A non-electric proportional dispenser (Dosatron DI16-11GPM, Dosatron International Inc., Bordeaux, France) was used to inject the correct rate of $\mathrm{N}$ fertilizer in each fertigation event. This system used the water pressure (0.3-6 bar) as a driving force to suck up the fertilizers from the tank and mix them homogeneously with the irrigation water. This process took place in a mixer section to assure the correct application rate, independent of the water flow or pressure variations.

In the plots with drip irrigation, a system was used that had one pressure-compensated irrigation line for each pair of maize lines. Consequently, each plot had half of the surface between rows with drip lines ("wet area") and half without drip lines ("dry area"). Each line had 20 emitters (nominal discharge of $4 \mathrm{Lh}^{-1}$ ), $0.33 \mathrm{~m}$ apart. Irrigation was carried out three times per week with a total of 48 and 44 irrigation events during 2014 and 2015, respectively. In 
sprinkler plots, irrigation was carried out using a $12 \mathrm{~m} \times 12 \mathrm{~m}$ sprinkler irrigation system at a height of $2.5 \mathrm{~m}$. A total amount of 688 and $705 \mathrm{~mm}$ of water were applied during 2014 and 2015, respectively, from late May to early September. In sprinkler-irrigated plots, irrigation was performed twice per week, resulting in 32 and 31 events during 2014 and 2015, respectively. All plots received the same total amount of water by the end of the experiment, taking into account the flow and pressure of each water emitter. The water doses to be applied were estimated from the crop evapotranspiration (ETc) of the previous week (net water requirements). This was calculated daily as ETc. $=\mathrm{Kc} \times$ ETo, where ETo is the reference evapotranspiration calculated by the FAO Penman-Monteith method (Allen et al., 1998) using data from a meteorological station located in the experimental field. The crop coefficient (Kc) was obtained for the maize crop following the method of Allen et al. (1998). The field was kept free of weeds, pests and diseases, following local practices (e.g. herbicides, pesticides, etc.). The maize was harvested on 24th and 16th October in 2014 and 2015, respectively, and the maize stover was left on the ground and subsequently incorporated with a cultivator.

\subsection{GHG sampling and analyses}

Fluxes of $\mathrm{N}_{2} \mathrm{O}, \mathrm{CH}_{4}$ and $\mathrm{CO}_{2}$ were measured from April 2014 to late October 2016 using opaque manual circular static chambers as described in detail by Sanz-Cobena et al. (2014a). The chambers (diameter $35.6 \mathrm{~cm}$, height $19.3 \mathrm{~cm}$ ) were hermetically closed (during $1 \mathrm{~h}$ ) by fitting them into stainless steel rings, which were inserted at the beginning of the study into the soil to a depth of $5 \mathrm{~cm}$ to minimize the lateral diffusion of gases and avoid the soil disturbance associated with the insertion of the chambers in the soil. The rings were only removed during management events. One chamber was located in sprinkler-irrigated plots, while in the dripirrigated treatments two chambers (one in the wet and one in the dry areas) were used.

Gas samples were taken twice per week during the first month after all fertilization events. The gas sampling frequency was then gradually decreased until the next fertilization event (June 2015) or the end of the experiment (October 2015). Samples were taken at the same time of day (10-12 am) in order to minimize any effects of diurnal variations in the emissions (Reeves and Wang, 2015). Measurements of $\mathrm{N}_{2} \mathrm{O}, \mathrm{CO}_{2}$ and $\mathrm{CH}_{4}$ emissions were made at 0,30 and $60 \mathrm{~min}$ to test the linearity of gas accumulation in each chamber. The increases in $\mathrm{N}_{2} \mathrm{O}, \mathrm{CH}_{4}$ and $\mathrm{CO}_{2}$ concentrations within the chamber headspace were generally linear ( $>90 \%$ of cases, particularly when highest fluxes or emission peaks were reported, $\mathrm{R}^{2}>0.90$ ) during the sampling period $(1 \mathrm{~h})$. In the case of nonlinear fluxes, linear regressions were performed, since it has been described as the recommended option for three sampling points (Venterea et al., 2012).

The concentrations of $\mathrm{N}_{2} \mathrm{O}, \mathrm{CO}_{2}$ and $\mathrm{CH}_{4}$ were quantified by gas chromatography, using a HP-6890 gas chromatograph (GC) equipped with a headspace autoanalyzer (HT3), both from Agilent Technologies (Barcelona, Spain). HP Plot-Q capillary columns transported the gas samples to a ${ }^{63} \mathrm{Ni}$ electron-capture detector (ECD) to analyze the $\mathrm{N}_{2} \mathrm{O}$ concentrations and to a flame-ionization detector (FID) fitted with a methanizer for the $\mathrm{CH}_{4}$ and $\mathrm{CO}_{2}$ concentrations.

A gas flow-through system was used to measure the NO fluxes. One chamber per plot was used for this analysis (diameter $35.6 \mathrm{~cm}$, height $19.3 \mathrm{~cm}$ ). The interior of the chamber was covered with Teflon $^{\circledR}$ to minimize the reactions of NOx with the walls and with the chamber had inlet and outlet holes (Abalos et al., 2014b). The nitric oxide was analysed using a chemiluminiscence detector (AC31M-LCD, Environnement S.A., Poissy, France). During this measurement, air (filtered through a charcoal and aluminium $/ \mathrm{KMnO}_{4}$ column to remove $\mathrm{O}_{3}$ and NOx) was passed through the headspace of the chamber, and the gas samples were pumped from the chambers at a constant flow rate to the detection instruments through Teflon $^{\circledR}$ tubing. An ambient air sample was measured between chamber measurements. The NO flux was calculated from a mass balance equation, considering the flow rate of the air through the chamber and the increase in NO concentration with respect to the control (empty chamber) when the steady state was reached, as proposed by Kim et al. (1994).

\subsection{Soil and crop analyses}

To relate gas emissions to soil properties, soil samples were collected from a depth of $0-10 \mathrm{~cm}$ during the experimental period on almost all gas-sampling days, particularly after each fertilization event. Three soil cores were randomly sampled close to the ring in each plot and then mixed and homogenized in the laboratory. The soil $\mathrm{NH}_{4}{ }^{+}-\mathrm{N}$ and $\mathrm{NO}_{3}{ }^{-}-\mathrm{N}$ concentrations were analysed using $8 \mathrm{~g}$ of soil extracted with $50 \mathrm{~mL}$ of $\mathrm{KCl}(1 \mathrm{M})$ and measured by automated colorimetric determination using a flow injection analyzer (FIAS 400 Perkin Elmer) provided with a UV-V spectrophotometer detector. Soil DOC was determined by extracting $8 \mathrm{~g}$ of homogeneously mixed soil with $50 \mathrm{~mL}$ of deionized water and then analyzing the resulting solution with a total organic $C$ analyzer (multi N/C 3100 Analityk Jena) equipped with an IR detector. Water-filled pore space (WFPS) was calculated by dividing the volumetric water content by the total soil porosity. The total soil porosity was calculated according to the following relationship: soil porosity $=(1-$ soil bulk density/2.65), assuming a particle density of $2.65 \mathrm{~g} \mathrm{~cm}^{-3}$ (Danielson et al., 1986). The gravimetric water content was determined by oven-drying soil samples at $105^{\circ} \mathrm{C}$ with a MA30 Sartorius ${ }^{\circledR}$ moisture analyzer.

The maize was harvested at physiological maturity (black-layer stage). One sample in each plot, consisting of $5 \mathrm{Lm}$, was collected to determine the total grain (at $14 \%$ moisture level) and aboveground biomass yields. The total $\mathrm{C}$ and $\mathrm{N}$ content of the maize grain and above-ground biomass were determined by elemental analysis with a LECO TruMac CN analyzer ${ }^{\circledR}$.

\subsection{Calculations and statistical methods}

The cumulative $\mathrm{N}_{2} \mathrm{O}, \mathrm{CO}_{2}, \mathrm{CH}_{4}$ and $\mathrm{NO}$ fluxes were estimated by successive linear interpolations between the sampling dates. In drip irrigated plots, GHG and NO fluxes were calculated considering the weighted average, taking into account the surface area of each zone (wet: with drip irrigation line and dry: without drip irrigation line) within the plot (Abalos et al., 2014b). In addition, the cumulative fluxes of the wet and dry areas were also compared. The yieldscaled $\mathrm{N}_{2} \mathrm{O}$ emissions (YSNE) were expressed as the ratio between the amount of $\mathrm{N}$ emitted as $\mathrm{N}_{2} \mathrm{O}$ and the above-ground $\mathrm{N}$ uptake (van Groenigen et al., 2010).

The analysis of data was performed using Statgraphics Plus v. 5.1. Analyses of variance were performed for all variables throughout the experiment. Data distribution normality and variance uniformity were previously assessed by Shapiro-Wilk test and Leveneís statistic, respectively, and log-transformed before analysis when necessary. The means were separated by the LSD test at $P<0.05$. For non-normally distributed data, the Kruskal-Wallis test was used on non-transformed data to evaluate the differences at $P<0.05$. Linear correlations were carried out to determine the relationships between the gas fluxes and WFPS, soil temperature, DOC, $\mathrm{NH}_{4}{ }^{+}-\mathrm{N}$ and $\mathrm{NO}_{3}{ }^{-}-\mathrm{N}$. These analyses were performed using the mean/cumulative data of the replicates of all the fertilizerirrigation treatments (including both dry and wet areas of the drip-irrigated plots), and also for all the days when the soil and GHG were simultaneously sampled. 


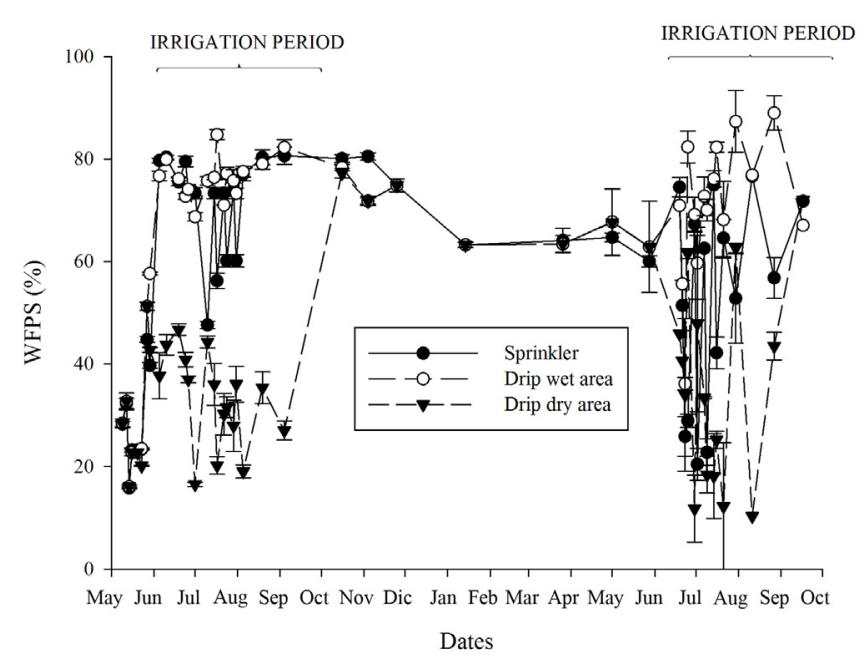

Fig. 1. Evolution of soil water-filled pore space (WFPS, \%) in the sprinkler and drip irrigation plots (wet and dry areas). Vertical bars indicate standard errors.

\section{Results}

\subsection{Environmental conditions and soil WFPS}

The mean soil temperature (at $10 \mathrm{~cm}$ depth) during the maize cropping period was 20.7 and $20.5^{\circ} \mathrm{C}$ in 2014 and 2015 , respectively, which were typical values in the experimental area. During the intercrop period, the mean soil temperature was $9.2^{\circ} \mathrm{C}$ and the accumulated rainfall was $218 \mathrm{~mm}$. The evolution of WFPS in sprinkler and drip-irrigated plots is shown in Fig. 1. The values ranged from 10 to $88 \%$ during the maize cropping period. The WFPS fluctuated more in the $S$ plots (two irrigation events per week) than in the D plots (three irrigation events per week) during the irrigation period. The dry areas in the D plots had significantly lower WFPS values than the wet areas or the $S$ plots $(P<0.05)$, except after rainfall events or when irrigation was not carried out.

\subsection{Mineral $N$ and $D O C$}

During maize cropping phase, three different periods have been considered for the average mineral $\mathrm{N}$ concentration in the topsoil (Fig. 2): Period I (from the beginning of maize cropping period to the first fertigation event -not included-, involving the fertilization of sprinkler-irrigated treatments); Period II (from the first to the second fertigation event) and Period III (from the second fertigation event to harvest). During the intercrop period, topsoil $\mathrm{NH}_{4}{ }^{+}$ and $\mathrm{NO}_{3}{ }^{-}$contents were always $<5$ and $10 \mathrm{mg} \mathrm{N} \mathrm{kg} \mathrm{soil}{ }^{-1}$, respectively, without significant differences between treatments (data not shown).

The topsoil $\mathrm{NH}_{4}{ }^{+}$content increased markedly after $\mathrm{N}$ fertilizer application. In both years, a significant enhancement of average $\mathrm{NH}_{4}{ }^{+}$concentrations in the case of CAN + NI-S, with respect to CAN-S, was observed (Fig. 2a, b). This increment was observed during Period I (in both years) and Period II (only in 2015). During 2014, concentrations in the sprinkler-irrigated plots decreased rapidly to values below $10 \mathrm{mg} \mathrm{N} \mathrm{kg} \mathrm{soil}{ }^{-1}$, while in 2015 the average $\mathrm{NH}_{4}{ }^{+}$topsoil concentrations in the CAN + NI-S treatment were $>35 \mathrm{mg} \mathrm{N} \mathrm{kg}^{-1}$ in Period II and III. No effect of the UI-S on average $\mathrm{NH}_{4}{ }^{+}$concentrations was observed (Fig. 2c, d), although during 2014, this treatment tended to decrease $\mathrm{NH}_{4}{ }^{+}$content, with respect to U-S. The application of $\mathrm{N}$-fertilizers through fertigation resulted in U-D and CAN-D having significantly higher average $\mathrm{NH}_{4}{ }^{+}$contents during Period III (in both years) and Period II (in 2014), than in the non-fertilized treatments (Fig. 2a-d). In the fertigated plots, $\mathrm{NH}_{4}{ }^{+}$concentrations were significantly higher in the wet than in the dry areas (Fig. S1 in the online version, at http://dx.doi.org/10. 1016/j.fcr.2017.01.009).

The CAN + NI-S treatment significantly decreased $\mathrm{NO}_{3}{ }^{-}$concentrations in both years, compared with CAN without DMPSA, during Period I (Fig. 2e, f). With regards to the U-based treatments, the UI-S treatment decreased $\mathrm{NO}_{3}{ }^{-}$concentrations numerically (but not statistically) compared with U-S. Both fertigated treatments had the highest average $\mathrm{NO}_{3}{ }^{-}$concentrations during Period II and III (Fig. 2e-h) during 2014, with concentrations above $20 \mathrm{mg} \mathrm{N} \mathrm{kg} \mathrm{soil}^{-1}$ until September. During 2015, increases in the fertigated plots were only significant with respect to C-S. Generally, $\mathrm{NO}_{3}{ }^{-}$contents were significantly higher in 2015 than in 2014 in sprinkler-fertilized treatments (U-S, UI-S, CAN-S, CAN + NI-S), but the opposite trend was observed for fertigated treatments (U-D, CAN-D) $(P<0.05)$. In contrast to the $\mathrm{NH}_{4}{ }^{+}$concentrations, those of $\mathrm{NO}_{3}-$ were significantly higher in the dry than in the wet areas (although no differences were found in CAN-D during 2015) (Fig. $\mathrm{S} 1$ in the online version, at http://dx.doi.org/10.1016/j.fcr.2017.01. 009).

Daily DOC contents ranged from 28 to $171 \mathrm{mg} \mathrm{C} \mathrm{kg} \mathrm{soil}^{-1}$ with the highest concentrations during the two months following $\mathrm{N}$ fertilization (data not shown). Average DOC concentrations during maize cropping period are shown in Fig. $2 \mathrm{i}$ and j. On average, DOC was significantly higher in 2015 than in 2014. Drip-irrigated treatments had the lowest average DOC contents during 2014, and differences between treatments during 2015 were negligible. Accordingly, in sprinkler-irrigated plots, $\mathrm{N}$-fertilized treatments increased DOC contents with respect to C-S, but only during 2014 .

\subsection{Emissions of $N$ oxides}

Daily $\mathrm{N}_{2} \mathrm{O}$ emissions from late-May to late-August (which includes the emission peaks) are shown in Fig. 3. During the intercrop period, all $\mathrm{N}_{2} \mathrm{O}$ fluxes were $<0.1 \mathrm{mg} \mathrm{N} \mathrm{m}^{-2} \mathrm{~d}^{-1}$, accounting for less than $10 \%$ of total cumulative emissions during maize cropping periods (data not shown). No significant differences between treatments were observed during this period. Nitrous oxide fluxes ranged from -0.1 (UI-S on 14th January 2014) to $22.3 \mathrm{mg} \mathrm{N} \mathrm{m}^{-2}$ $\mathrm{d}^{-1}$ (U-S on 19th June 2015). Emission peaks were observed after each fertilization event. Cumulative fluxes in 2014 decreased in the order: U-SCAN-S > inhibitors > fertigation > control $(P<0.05)$ (Table 1). In 2015, cumulative fluxes decreased in the order $\mathrm{U}-\mathrm{S}>\mathrm{CAN}-\mathrm{S}=\mathrm{UI}-\mathrm{S}>\mathrm{CAN}+\mathrm{NI}-\mathrm{S}=$ fertigated treatments $=$ control $(P<0.05)$. Emissions of $\mathrm{N}_{2} \mathrm{O}$ were significantly higher in 2015 than in 2014. In drip plots, a zone effect was found, with $\mathrm{N}_{2} \mathrm{O}$ emissions being higher in the wet areas than in the dry areas (Fig. S2 in the online version, at http://dx.doi.org/10.1016/j.fcr.2017.01.009). A positive correlation of $\mathrm{N}_{2} \mathrm{O}$ fluxes with $\mathrm{NH}_{4}{ }^{+}(\mathrm{r}=0.61, \mathrm{n}=66$, $P<0.001)$ and $\mathrm{NO}_{3}{ }^{-}(\mathrm{r}=0.42, \mathrm{n}=61, P<0.01)$ concentrations was obtained.

Fig. 4 shows daily NO emissions including the emission burst (summer period). During the intercrop period, all NO fluxes were $<2 \mathrm{mg} \mathrm{N} \mathrm{m}^{-2} \mathrm{~d}^{-1}$ and cumulative fluxes were statistically similar in all treatments. Nitric oxide emissions ranged from 0.4 to $10.4 \mathrm{mg} \mathrm{N} \mathrm{m}^{-2} \mathrm{~d}^{-1}$ in 2014 and from -0.1 to $198.8 \mathrm{mg} \mathrm{N} \mathrm{m}^{-2} \mathrm{~d}^{-1}$ in 2015. During 2014, no significant differences between treatments were found in cumulative NO emissions (Table 1). In 2015, cumulative NO emissions decreased in the order CAN-S $>$ CAN + NI$\mathrm{S}>$ CAN-D (for CAN-based treatments) and U-S > UI-S > U-D (for U-based treatments) $(P<0.05)$. As for $\mathrm{N}_{2} \mathrm{O}$ emissions, CAN$\mathrm{S}$ significantly decreased NO emissions with respect to U-S in the second year. Nitric oxide emissions correlated significantly with $\mathrm{N}_{2} \mathrm{O}$ emissions $(\mathrm{r}=0.61, \mathrm{n}=61, P<0.001), \mathrm{NH}_{4}^{+}(\mathrm{r}=0.61$, 
2014
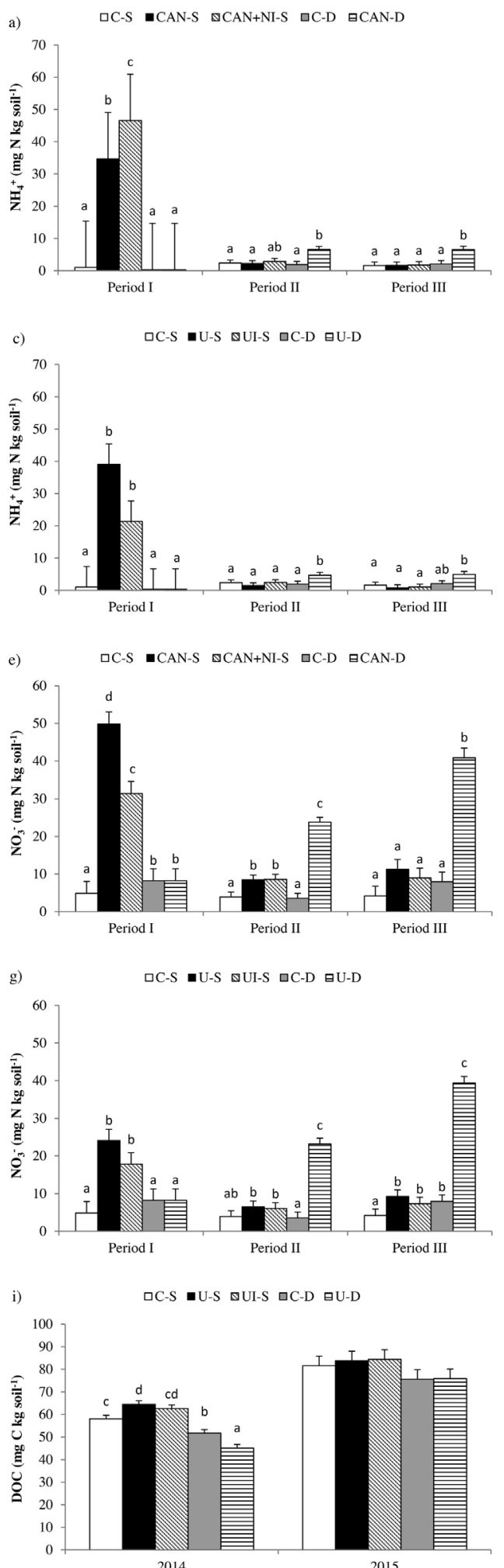

2015
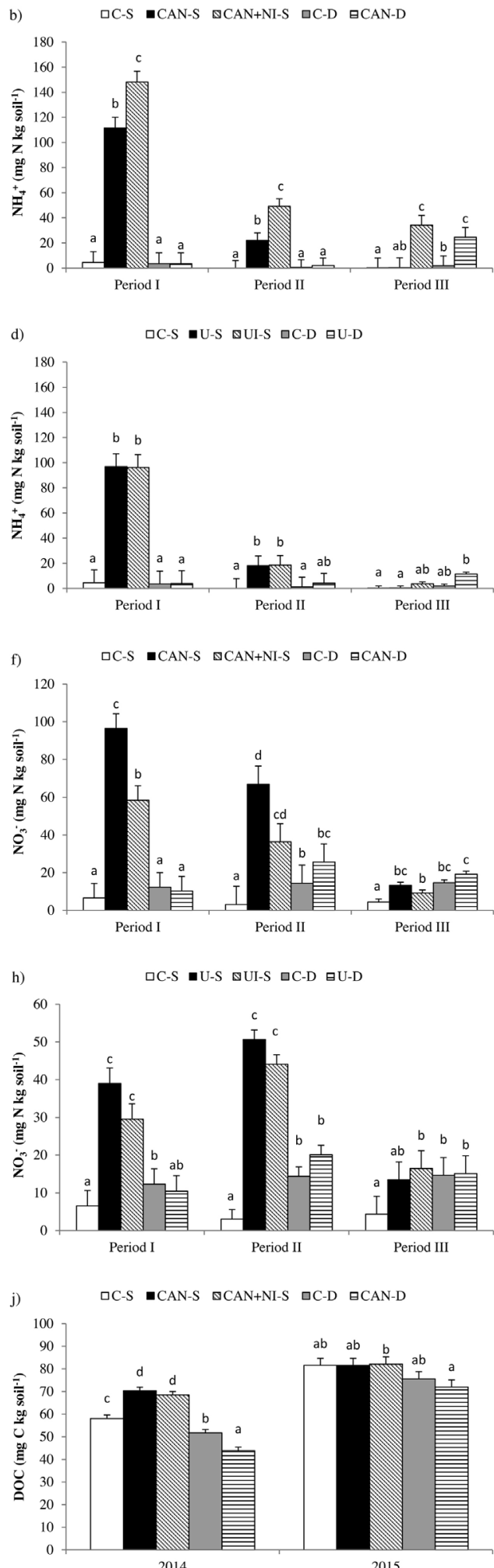

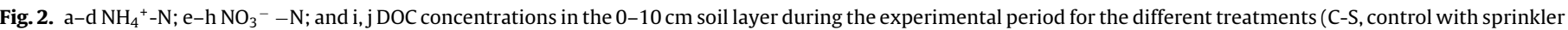

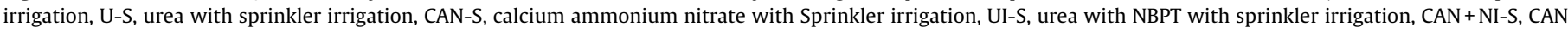

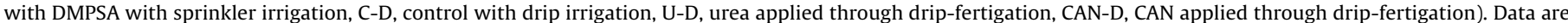

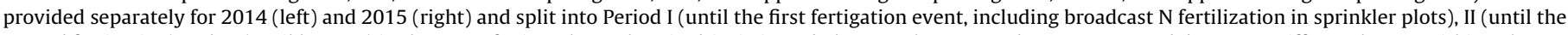

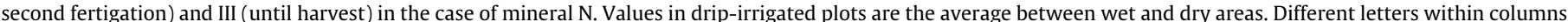
indicate significant differences within each period of year, by applying the LSD test at $P<0.05$. Vertical bars indicate standard errors of the ANOVA. 
a)

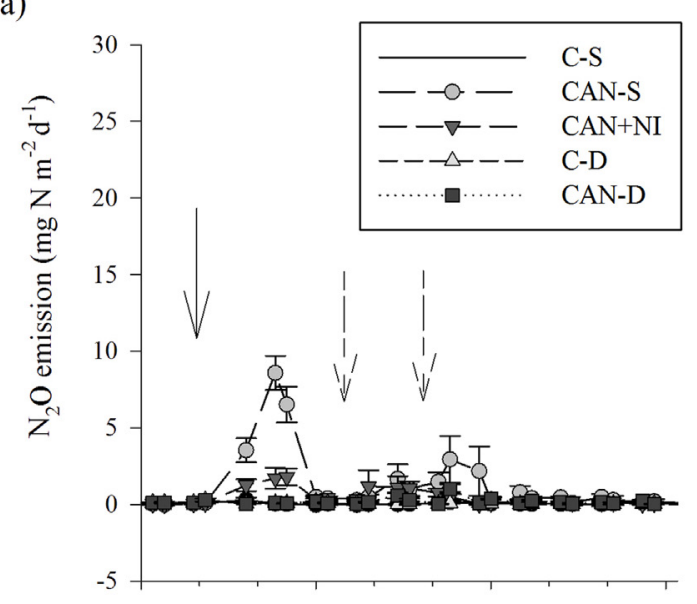

c)

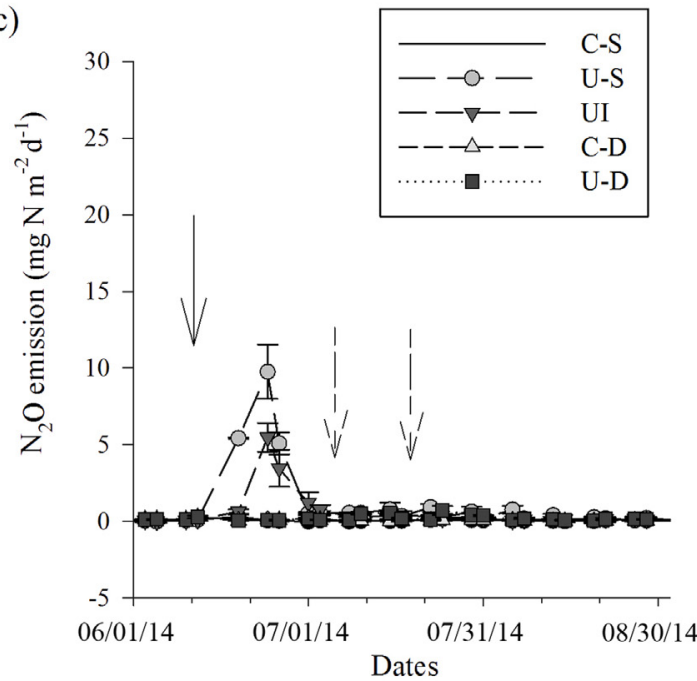

b)

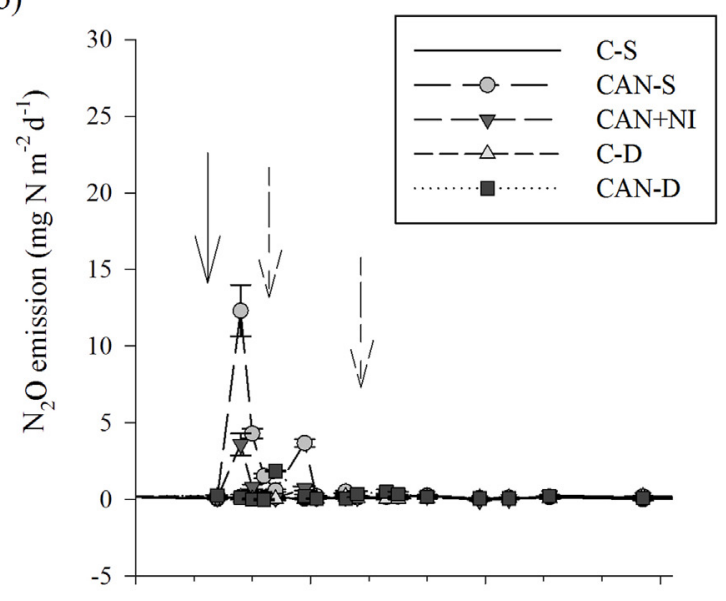

d)

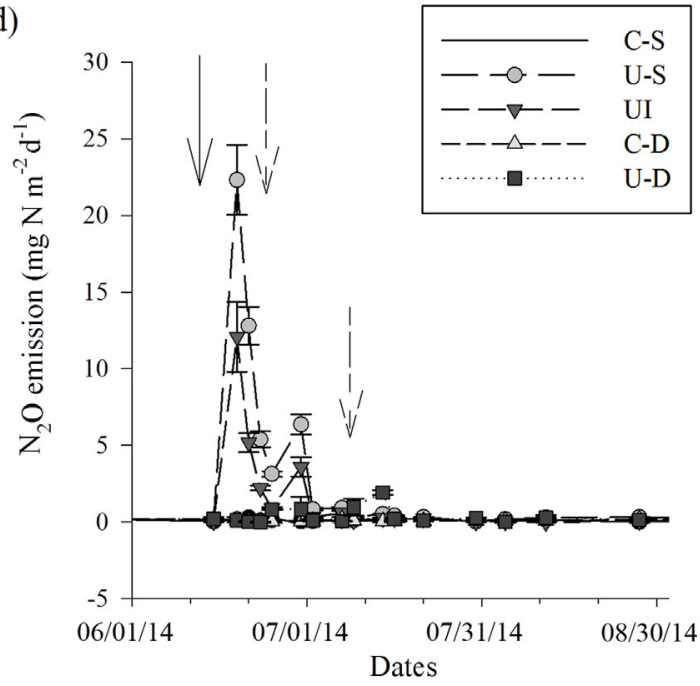

Fig. 3. Daily $\mathrm{N}_{2} \mathrm{O}$ emissions during summer the period for the different treatments (C-S, control with sprinkler irrigation, U-S, urea with sprinkler irrigation, CAN-S, calcium ammonium nitrate with Sprinkler irrigation, UI-S, urea with NBPT with sprinkler irrigation, CAN + NI-S, CAN with DMPSA with sprinkler irrigation, C-D, control with drip irrigation, U-D, urea applied through drip-fertigation, CAN-D, CAN applied through drip-fertigation). Data are provided separately for 2014 (left) and 2015 (right). Values in drip-irrigated plots are the average between wet and dry areas. The solid and dotted arrows indicate the time of $\mathrm{N}$ fertilization in sprinkler plot and the beginning of each fertigation, respectively. Vertical bars indicate standard errors.

Table 1

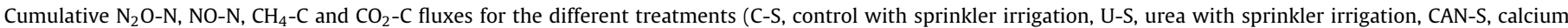

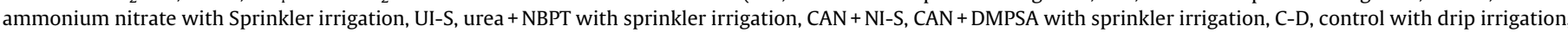

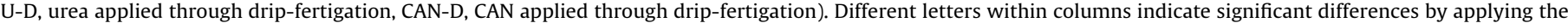
LSD test at $P<0.05$. Standard Error (S.E.) is given for each effect.

\begin{tabular}{|c|c|c|c|c|c|c|c|c|}
\hline \multirow[t]{2}{*}{ Treatment } & \multicolumn{2}{|c|}{ 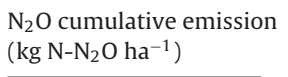 } & \multicolumn{2}{|c|}{$\begin{array}{l}\text { NO cumulative emission } \\
\left(\mathrm{kg} \mathrm{N}-\mathrm{NO} \mathrm{ha}^{-1}\right)\end{array}$} & \multicolumn{2}{|c|}{$\begin{array}{l}\mathrm{CH}_{4} \text { cumulative emission } \\
\left(\mathrm{g} \mathrm{C}^{-} \mathrm{CH}_{4} \mathrm{ha}^{-1}\right)\end{array}$} & \multicolumn{2}{|c|}{$\begin{array}{l}\mathrm{CO}_{2} \text { cumulative emission } \\
\left(\mathrm{Mg} \mathrm{C}-\mathrm{CO}_{2} \mathrm{ha}^{-1}\right)\end{array}$} \\
\hline & 2014 & 2015 & 2014 & 2015 & 2014 & 2015 & 2014 & 2015 \\
\hline $\mathrm{C}-\mathrm{S}$ & $0.17 \mathrm{~b}$ & $0.26 \mathrm{a}$ & 2.19 & $0.45 \mathrm{a}$ & $-327.40 \mathrm{abc}$ & $-84.59 \mathrm{~b}$ & $6.68 \mathrm{~b}$ & $3.73 \mathrm{bcd}$ \\
\hline C-D & $0.10 \mathrm{a}$ & $0.08 \mathrm{a}$ & 2.68 & $1.18 \mathrm{~b}$ & $0.28 \mathrm{~d}$ & $-1071.08 \mathrm{a}$ & $2.13 \mathrm{a}$ & $2.24 \mathrm{a}$ \\
\hline U-S & $1.32 \mathrm{~d}$ & $2.01 \mathrm{c}$ & 2.58 & $14.42 \mathrm{f}$ & $-541.77 \mathrm{ab}$ & $-542.38 \mathrm{a}$ & $6.26 \mathrm{~b}$ & $5.12 \mathrm{e}$ \\
\hline CAN-S & $1.45 \mathrm{~d}$ & $1.14 \mathrm{~b}$ & 2.72 & $9.06 \mathrm{e}$ & $-592.50 \mathrm{a}$ & $-481.59 \mathrm{a}$ & $5.96 \mathrm{~b}$ & 3.91 cde \\
\hline UI-S & $0.56 \mathrm{c}$ & $1.10 \mathrm{~b}$ & 2.32 & $4.14 \mathrm{~d}$ & $-524.80 \mathrm{ab}$ & $-425.72 \mathrm{a}$ & $5.56 \mathrm{~b}$ & 4.33 cde \\
\hline $\mathrm{CAN}+\mathrm{NI}-\mathrm{S}$ & $0.61 \mathrm{c}$ & $0.48 \mathrm{a}$ & 2.38 & $2.16 \mathrm{c}$ & $-252.25 \mathrm{bcd}$ & $-713.37 \mathrm{a}$ & $6.61 \mathrm{~b}$ & $4.28 \mathrm{de}$ \\
\hline U-D & $0.24 \mathrm{~b}$ & $0.52 \mathrm{a}$ & 3.58 & $1.30 \mathrm{~b}$ & $-122.45 \mathrm{~cd}$ & $-1239.28 \mathrm{a}$ & $2.35 \mathrm{a}$ & $2.52 \mathrm{ab}$ \\
\hline CAN-D & $0.25 \mathrm{~b}$ & $0.27 \mathrm{a}$ & 3.76 & $1.27 \mathrm{~b}$ & $-138.71 \mathrm{~cd}$ & $-1366.77 \mathrm{a}$ & $2.25 \mathrm{a}$ & $3.00 a b c$ \\
\hline S.E. & 0.10 & 0.17 & 0.54 & 0.96 & 108.56 & 168.45 & 0.53 & 0.39 \\
\hline
\end{tabular}



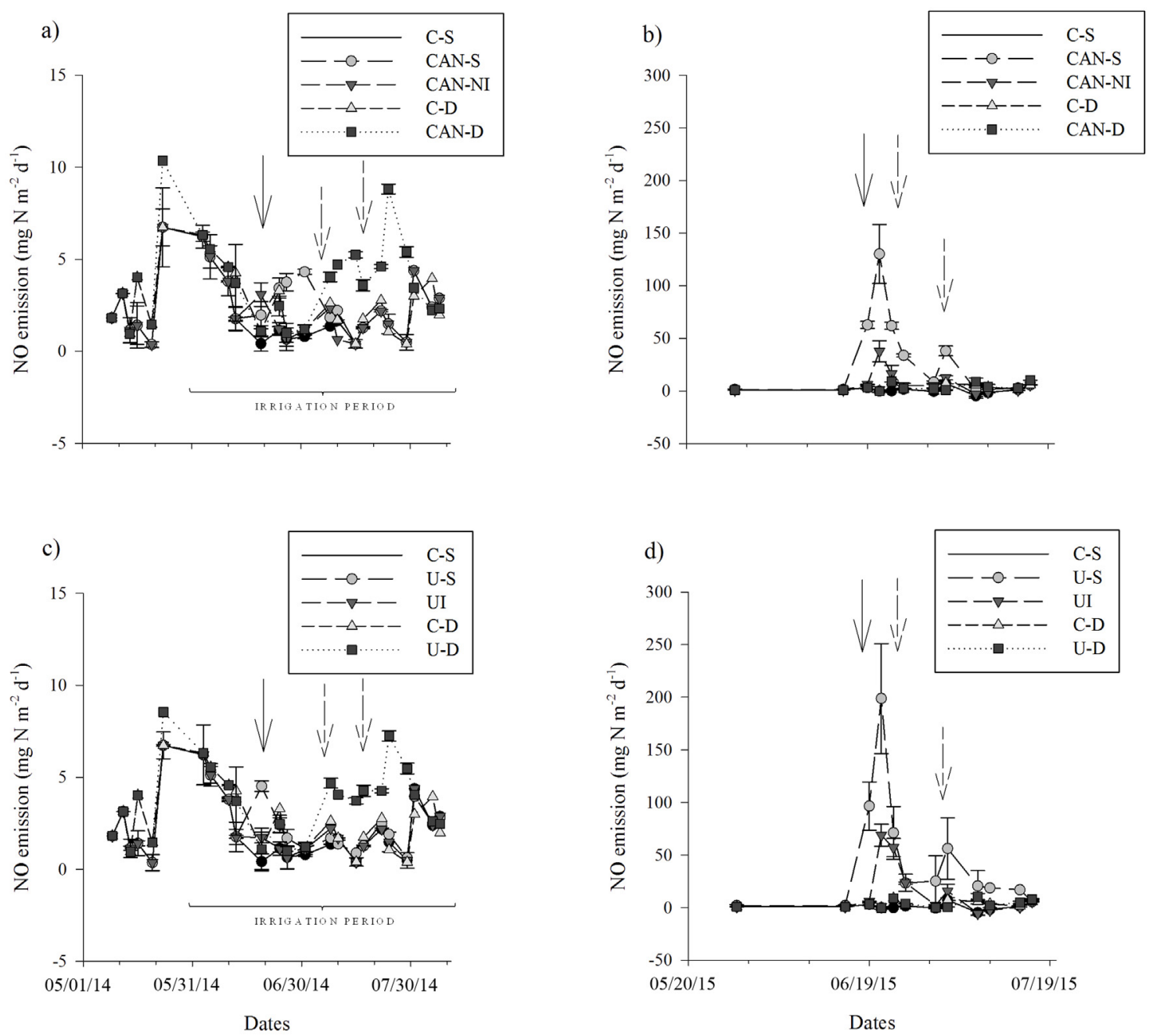

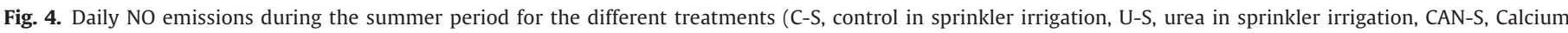

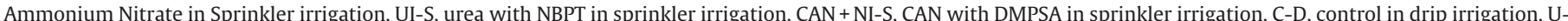

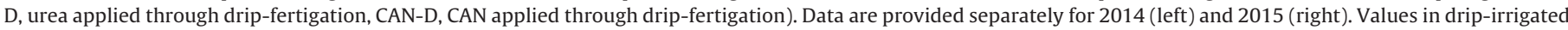

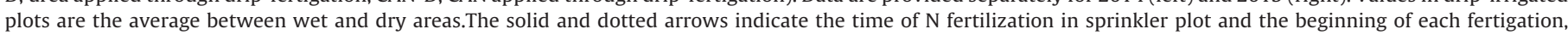
respectively. Vertical bars indicate standard errors.

$\mathrm{n}=61, \mathrm{P}<0.001)$ and $\mathrm{NO}_{3}{ }^{-}(\mathrm{r}=0.49, \mathrm{n}=61, \mathrm{P}<0.001)$ during both years.

\section{4. $\mathrm{CH}_{4}$ emission and respiration rates}

All fertilizer-irrigation combinations were net $\mathrm{CH}_{4}$ sinks, although daily fluxes ranged from -1.5 to $0.8 \mathrm{mg} \mathrm{C} \mathrm{m}^{-2} \mathrm{~d}^{-1}$ (data not shown). Cumulative $\mathrm{CH}_{4}$ uptake was significantly higher in $\mathrm{U}-$ $S$ than in U-D (Table 1) and in CAN-S than in CAN + NI-S/CAN-D. Methane fluxes inversely correlated with $\mathrm{NH}_{4}{ }^{+}(\mathrm{r}=-0.41, \mathrm{n}=33$, $P<0.05)$ and DOC $(\mathrm{r}=-0.51, \mathrm{n}=33, P<0.01)$ concentrations during 2014. Respiration fluxes ranged from 0.1 to $7.8 \mathrm{~g} \mathrm{C} \mathrm{m}^{-2} \mathrm{~d}^{-1}$. In 2014, cumulative respiration fluxes were significantly larger in sprinkler irrigation treatments $(P<0.05)$ (Table 1$)$. In 2015 , this tendency continued, but differences were only significant between the control treatments, $U-D$ versus $U-S$, and CAN-D versus CAN + NI-S. In drip-irrigated treatments, respiration rates were lower in the dry than in the wet areas $(P<0.05)$ (data not shown). The U treatment had the highest respiration rates. These fluxes correlated with $\mathrm{N}_{2} \mathrm{O}$ emissions $(\mathrm{r}=0.67, \mathrm{n}=61, P<0.001)$, soil temperature $(\mathrm{r}=0.67$, $\mathrm{n}=61, P<0.001), \mathrm{NH}_{4}{ }^{+}(\mathrm{r}=0.47, \mathrm{n}=61, P<0.05)$ and $\mathrm{NO}_{3}{ }^{-}(\mathrm{r}=0.32$, $\mathrm{n}=61, P<0.05)$. During the intercrop period, all respiration rates were $<2 \mathrm{~g} \mathrm{C} \mathrm{m}^{-2} \mathrm{~d}^{-1}$, and neither $\mathrm{CH}_{4}$ uptake nor $\mathrm{CO}_{2}$ emissions were significantly affected by the different treatments.

\subsection{Yield parameters and YSNE}

Grain yield (Table 2) was not significantly influenced by the alternative management strategies in either of the two years. In 2014, biomass yield decreased in the order fertigation treatments > inhibitors $=U-S=C A N-S>$ control. In 2015, biomass production in Ubased treatments was not significantly different, while CAN + NI-S and CAN-D increased biomass production by $26 \%$ and $34 \%$, respectively, with respect to CAN-S. Consequently, YSNE during 2014 decreased in the order conventional treatments $>$ inhibitors $>$ fertigation for both $U$ and CAN-based treatments $(P<0.05)$ (Table 2). In 2015, both CAN + NI-S and CAN-D decreased YSNE with respect to CAN-S (71 and 76\%, respectively) while U-D significantly decreased YSNE compared with U-S and U-I. Similarly to the grain yield, the alternative management strategies did not affect $\mathrm{N}$ uptake by in either of the two years (Table 2). 
Table 2

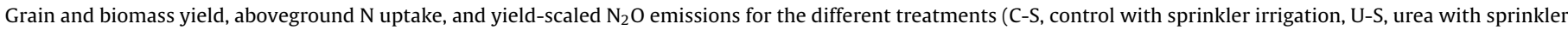

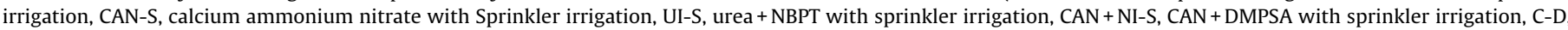

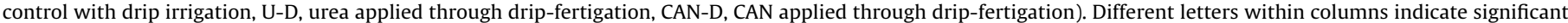
differences by applying the LSD test at $P<0.05$. Standard Error (S.E.) is given for each effect.

\begin{tabular}{|c|c|c|c|c|c|c|c|c|}
\hline \multirow[t]{2}{*}{ Treatment } & \multicolumn{2}{|c|}{ Grain yield $\left(\mathrm{kg} \mathrm{ha}^{-1}\right)$} & \multicolumn{2}{|c|}{ Biomass yield $\left(\mathrm{kg} \mathrm{ha}^{-1}\right)$} & \multicolumn{2}{|c|}{$\begin{array}{l}\text { Aboveground } \mathrm{N} \text { uptake } \\
\left(\mathrm{kgNha}^{-1}\right)\end{array}$} & \multicolumn{2}{|c|}{$\begin{array}{l}\text { Yield-scaled } \mathrm{N}_{2} \mathrm{O} \\
\text { emissions }\left(\mathrm{g} \mathrm{kg}^{-1}\right)\end{array}$} \\
\hline & 2014 & 2015 & 2014 & 2015 & 2014 & 2015 & 2014 & 2015 \\
\hline$C-S$ & 3540 a & $4810 \mathrm{a}$ & 8476 a & 21857 a & $77 \mathrm{a}$ & $167 \mathrm{a}$ & 2.84 cde & $3.00 \mathrm{abc}$ \\
\hline C-D & $5122 \mathrm{a}$ & $4324 \mathrm{a}$ & $17143 \mathrm{~b}$ & 20571 a & $104 \mathrm{a}$ & $92 \mathrm{a}$ & $1.01 \mathrm{a}$ & $0.91 \mathrm{a}$ \\
\hline U-S & $15598 \mathrm{~b}$ & $12031 \mathrm{~b}$ & 26857 c & 41238 bc & $278 \mathrm{~b}$ & 394 b & $4.91 \mathrm{de}$ & $5.48 c$ \\
\hline CAN-S & 17079 b & $11713 \mathrm{~b}$ & $24762 \mathrm{c}$ & $33500 \mathrm{~b}$ & $260 \mathrm{~b}$ & $276 \mathrm{~b}$ & $5.61 \mathrm{e}$ & $4.35 \mathrm{bc}$ \\
\hline UI & 14997 b & $12653 \mathrm{~b}$ & 25952 c & 41000 bc & $247 \mathrm{~b}$ & $361 \mathrm{~b}$ & $2.26 \mathrm{bc}$ & $3.06 \mathrm{abc}$ \\
\hline CAN-NI & 14982 b & $14638 \mathrm{~b}$ & $25714 \mathrm{c}$ & 42071 c & $246 \mathrm{~b}$ & $379 \mathrm{~b}$ & $2.54 \mathrm{~cd}$ & $1.25 \mathrm{a}$ \\
\hline U-F & 12076 b & $12726 b$ & $36667 \mathrm{~d}$ & 39333 bc & $248 \mathrm{~b}$ & $259 \mathrm{~b}$ & $1.00 \mathrm{a}$ & $2.02 \mathrm{ab}$ \\
\hline CAN-F & $12598 \mathrm{~b}$ & $13213 b$ & $34286 \mathrm{~d}$ & 44810 c & $249 \mathrm{~b}$ & $252 \mathrm{~b}$ & $1.10 \mathrm{ab}$ & $1.07 \mathrm{a}$ \\
\hline S.E. & 1328 & 1766 & 2009 & 2620 & 27 & 52 & 0.55 & 0.90 \\
\hline
\end{tabular}

\section{Discussion}

\subsection{Effect of alternative management strategies (inhibitors/fertigation) on $\mathrm{N}_{2} \mathrm{O}$ and $\mathrm{NO}$ emissions}

Compared with CAN alone, the new NI DMPSA significantly reduced $\mathrm{N}_{2} \mathrm{O}$ emissions in 2014 (57\% abatement) and 2015 (58\% abatement) (Table 1). To date, several studies have demonstrated the effectiveness of pyrazole-based inhibitors, such as DMPP, for mitigating $\mathrm{N}_{2} \mathrm{O}$ losses (Akiyama et al., 2010; Gilsanz et al., 2016). However, no information on the effect of DMPSA has been published yet. Our results confirm that this inhibitor can significantly inhibit nitrification, resulting in lower $\mathrm{NO}_{3}{ }^{-}$contents and higher $\mathrm{NH}_{4}{ }^{+}$concentrations after $\mathrm{N}$ addition (Fig. 2a, b, e, f), thus abating $\mathrm{N}_{2} \mathrm{O}$ losses from both nitrification (directly) and denitrification (indirectly, by decreasing the availability of the substrate for denitrifiers) (Firestone and Davidson, 1989). The inhibitory effect obtained in our study surpassed that reported by Gilsanz et al. (2016) for DMPP in croplands for sandy-clay loam soils (average reduction of $24 \%$ ). The predominance of nitrification in low-C content soils of semi-arid areas (Aguilera et al., 2013) could have contributed to the high efficiency we observed. The effect of DMPSA on NO losses was less consistent, with a reduction of 5\% (which was not statistically significant) and 76\% in 2014 and 2015, respectively. Since nitrification has been described as the main source of NO (Skiba et al., 1997), we speculate that soil moisture conditions during the first week after $\mathrm{N}$ addition were more favorable for nitrification during 2015 (when irrigation events were performed 1 and 6 days after $\mathrm{N}$ addition). Water-filled pore space ranged from $48 \%$ to $52 \%$ when the NO peak was observed $(06 / 21 / 2015)$, which are optimum values for the predominance of nitrification (Pilegaard, 2013). In the previous year (when irrigation events were performed 1,3 and 6 days after fertilization), WFPS was above $70 \%$. Our results suggest that irrigation management (frequency and water regime) during the first days after $\mathrm{N}$ fertilization may play a key role in the effectiveness of NIs at reducing NO losses, particularly during periods with high microbial activity (i.e. summer crops with high soil temperatures). Our study also supports the potential of NIs to mitigate NO losses, as shown by recent meta-analysis studies (Qiao et al., 2015; Yang et al., 2016).

The use of urease inhibitors such as NBPT is recommended as a management option for reducing $\mathrm{NH}_{3}$ losses (Sanz-Cobena et al., 2014b), but also shows promising results for the abatement of $\mathrm{N}$ oxides under non-irrigated (Abalos et al., 2012) and irrigated conditions (Sanz-Cobena et al., 2012). As observed for DMPSA, the UI-S treatment significantly reduced $\mathrm{N}_{2} \mathrm{O}$ emissions (by $58 \%$ and $45 \%$ in 2014 and 2015, respectively) compared with U alone, while NO emissions were only significantly mitigated during 2015 (by 71\%)
(Table 1). In an irrigated assay performed in the same experimental area, Sanz-Cobena et al. (2012) found that the effect of NBPT in both $\mathrm{N}_{2} \mathrm{O}$ and $\mathrm{NO}$ emissions was very influenced by the irrigation management during the following weeks after fertilization, with negligible effect at the highest irrigation frequency. This was also observed in our experiment for NO, whereas $\mathrm{N}_{2} \mathrm{O}$ was significantly reduced in both years in the case of UI-S, compared with U-S. The correlation of $\mathrm{NH}_{4}{ }^{+}$topsoil concentrations with both $\mathrm{N}_{2} \mathrm{O}$ and $\mathrm{NO}$ emissions, as well as a $\mathrm{NO} / \mathrm{N}_{2} \mathrm{O}$ ratio $>1$, confirmed the important role played by nitrification. A slower release of $\mathrm{NH}_{4}{ }^{+}$can result in lower nitrification rates (Zaman et al., 2009), which in turn would reduce the availability of the $\mathrm{NO}_{3}{ }^{-}$substrate for denitrification (Abalos et al., 2012). In our study, topsoil $\mathrm{NO}_{3}{ }^{-}$concentrations tended to decrease in UI-S compared with U-S, but differences were not statistically significant (Fig. 2g, h).

Increases in water and nutrient use efficiency make dripfertigation an advisable strategy to improve plant nutrition and reduce nutrient losses (e.g. N) (Kennedy et al., 2013). Our results demonstrated that the application of $U$ and CAN through fertigation significantly decreased $\mathrm{N}_{2} \mathrm{O}$ emissions during both years, when compared with conventional management (sprinkler irrigation, U$\mathrm{S}$ and CAN-S). Fertigation mitigated $\mathrm{N}_{2} \mathrm{O}$ emissions by $83 \%$ in the case of CAN, and $81 \%$ the case of $U$, during 2014. Moreover, fertigation even decreased $\mathrm{N}_{2} \mathrm{O}$ losses compared to inhibitor-based treatments $(P<0.05)$. This was also observed during 2015, when $U$ D decreased $\mathrm{N}_{2} \mathrm{O}$ cumulative losses by 53 and $75 \%$ compared with UI-S and U-S, respectively. With regards to CAN-based treatments, CAN-D mitigated $\mathrm{N}_{2} \mathrm{O}$ emissions by $44 \%$ (not statistically significant at $P=0.05$ ) and $76 \%$, with respect to CAN + NI-S and CAN-S, respectively. Kennedy et al. (2013) found a significant reduction of $\mathrm{N}_{2} \mathrm{O}$ losses when an integrated management (including fertigation) was implemented, compared with conventional management including furrow irrigation. Lower soil mineral $\mathrm{N}$ concentrations observed in the fertigation treatment could explain these results (Fig. 2). In our study, maximum $\mathrm{NH}_{4}{ }^{+}$concentrations where significantly lower in the fertigated treatments $(P<0.05)$, while $\mathrm{NO}_{3}{ }^{-}$ contents were also generally lower in fertigated than in conventional treatments (Fig. 2). These results may suggest an effective $\mathrm{N}$ uptake as a result of application method and timing, although differences between treatments in aboveground $\mathrm{N}$ uptake were not significant (Table 2). Moreover, the WFPS distribution showed that in dry areas values were mostly below levels that promote the highest $\mathrm{N}_{2} \mathrm{O}$ losses (50-70\%) (Linn and Doran, 1984), while WFPS values in the wet areas (sometimes above $80 \%$ ) may have favored the reduction of $\mathrm{N}_{2} \mathrm{O}$ to $\mathrm{N}_{2}$, thus decreasing $\mathrm{N}_{2} \mathrm{O}$ losses. This agrees with Maris et al. (2015) who found that highest emissions in a fertigated olive orchard were observed at 60-80\% WFPS, as a result of denitrification. Moreover, WFPS values in wet areas 
were considerably less variable than those in S plots (with lower irrigation frequency). This suppressed the drying-rewetting cycles which promote coupled nitrification-denitrification (Guardia et al., 2016) and, therefore, high $\mathrm{N}_{2} \mathrm{O}$ losses in semi-arid areas. The different behavior in drip-irrigated soils of $\mathrm{NH}_{4}{ }^{+}$(less mobile, therefore may accumulate in the wet areas where moisture conditions favor denitrification) and $\mathrm{NO}_{3}{ }^{-}$ions (higher mobility, thus accumulating in the transition zone between the dry and wet areas with favorable conditions for nitrification) may have also contributed to the low emissions in drip-fertigated treatments (Vallejo et al., 2014). Indeed, higher $\mathrm{NO}_{3}{ }^{-}$and $\mathrm{NH}_{4}{ }^{+}$contents were observed in dry and wet areas, respectively (Fig. S1 in the online version, at http://dx. doi.org/10.1016/j.fcr.2017.01.009). The effect of fertigation on NO losses was only observed in 2015, due to the low emissions in 2014 (Fig. 4, Table 1). The application of CAN through drip-fertigation significantly mitigated NO emissions with respect to the conventional treatment CAN-S (86\%) and even CAN + NI-S (41\%). The spatial and temporal distribution of soil moisture and mineral $\mathrm{N}$ drove, as explained above, the low NO emissions in drip-fertigated treatments.

The experiment of Abalos et al. (2014b), performed in a fertigated watermelon crop under similar conditions, revealed that fertigation with urea instead of calcium nitrate increased $\mathrm{N}_{2} \mathrm{O}$ by a factor of 2.4. In our experiment, we did not find significant differences in $\mathrm{N}_{2} \mathrm{O}$ or NO losses between U-D and CAN-D (Table 1), with low emissions in both treatments. However, $\mathrm{N}_{2} \mathrm{O}$ and $\mathrm{NO}$ losses were significantly increased (by factors of 1.8 and 1.6, respectively) in U-S compared with CAN-S during 2015 (the year with highest $\mathrm{N}_{2} \mathrm{O}$ and NO losses). Ammonium-based fertilizers (such as urea) can produce $\mathrm{N}_{2} \mathrm{O}$ through both nitrification and denitrification processes. The importance of nitrification in semi-arid areas (Aguilera et al., 2013; Zhang et al., 2016), which was confirmed by the correlations of $\mathrm{N}_{2} \mathrm{O}$ losses with $\mathrm{NH}_{4}{ }^{+}$content and $\mathrm{NO}$ emissions, led to the $\mathrm{U}$ treatments releasing more $\mathrm{N}_{2} \mathrm{O}$ and NO than the CAN treatments $\left(50 \%\right.$ of $\mathrm{NH}_{4}^{+}-\mathrm{N}$ and $50 \%$ of $\mathrm{NO}_{3}{ }^{-}-\mathrm{N}$ ). This was observed for the irrigation system (sprinkler) and the campaign (2015) that had the most propitious conditions for nitrification during the first days following $\mathrm{N}$ fertilization.

\subsection{Effect of alternative management strategies (inhibitors/fertigation) on $\mathrm{CH}_{4}$ and $\mathrm{CO}_{2}$ emissions}

Methane oxidation capacity was barely affected by management treatments in both years (Table 1 ). Some studies have demonstrated that the effect of soil $\mathrm{NH}_{4}{ }^{+}$on $\mathrm{CH}_{4}$ uptake depends on $\mathrm{N}$ rate (small additions tend to stimulate $\mathrm{CH}_{4}$ oxidation, while large additions are inhibitory) (Veraart et al., 2015). Although the $\mathrm{N}$ rate used in our study ( $180 \mathrm{~kg} \mathrm{ha}^{-1}$ ) is above the threshold of $100 \mathrm{~kg} \mathrm{ha}^{-1}$ established in the meta-analysis of Aronson and Helliker (2010), our $\mathrm{N}$ rate was adjusted to maize demand, thus masking the effect of $\mathrm{NH}_{4}{ }^{+}$on methanotrophy. The lack of effect of NIs on $\mathrm{CH}_{4}$ is consistent with the meta-analyses of Qiao et al. (2015) and Yang et al. (2016) that show a non-significant tendency of inhibitors to decrease $\mathrm{CH}_{4}$ oxidation. Although the differences in $\mathrm{NH}_{4}{ }^{+}$content in the fertilized treatments were not enough to cause significant differences in $\mathrm{CH}_{4}$ uptake between them, the non-fertilized $\mathrm{C}-\mathrm{S}$ was the treatment that resulted in lowest $\mathrm{CH}_{4}$ uptake (significantly different to that of fertilized treatments) in 2015 (Table 2). Concerning drip-irrigated plots, the low $\mathrm{CH}_{4}$ sink measured during the first campaign was in agreement with Guardia et al. (2016), who argued that soil WFPS in the dry areas was too low to stimulate the activity of methanotrophic microorganisms. In the following campaign, differences were not statistically significant due to large variability of fluxes; but drip-irrigated plots resulted in numerically higher $\mathrm{CH}_{4}$ oxidation rates, due to higher methanotrophy after the irrigation period (October and November, data not shown). This effect suggests that the horizontal mobility of low amounts of residual mineral $\mathrm{N}$ towards dry areas in drip-irrigated plots (Fig. S1 in the online version, at doi:http://dx.doi.org/10.1016/j.fcr.2017.01.009) could have stimulated a $\mathrm{CH}_{4}$ sink after the first rainfall events in autumn (Aronson and Helliker, 2010). This would have increased soil moisture in dry areas thus making conditions favorable for methanotrophic activity (Le mer and Roger, 2001). In addition, this residual mineral $\mathrm{N}$ in dry areas could have promoted the suppression of methanogens (Malyan et al., 2016).

Soil respiration was only affected by the irrigation system (and not by fertilization), being significantly lower in drip-irrigated plots. Largest $\mathrm{CO}_{2}$ pulses are reported as a result of rewetting of dried soils (Liang et al., 2015), which are conditions that could be associated to sprinkler irrigation plots rather than the wet areas of drip-irrigated plots. Taking into account the global warming potential of $\mathrm{N}_{2} \mathrm{O}$ and $\mathrm{CH}_{4}$ over a 100 year time horizon (IPCC, 2014), $\mathrm{N}_{2} \mathrm{O}$ emissions mostly drove the GHG balance in this irrigated field since the average contribution of $\mathrm{CH}_{4}$ oxidation was $<10 \%$ (data not shown). Therefore, management practices for mitigating GHG emissons in irrigated semi-arid agro-ecosystems should, therefore, focus on $\mathrm{N}_{2} \mathrm{O}$ losses.

\subsection{Selecting the best management practices in irrigated maize}

Best management practices in irrigated maize must meet the pivotal goals of minimizing environmental impact (e.g. $\mathrm{N}$ losses) without penalizing crop yield. The scaling of $\mathrm{N}$ losses to $\mathrm{N}$ uptake (YSNE), which was introduced by van Groenigen et al. (2010), appears, therefore, to be a useful index to identify the most sustainable techniques. To be potentially acceptable by farmers, best management practices must not only minimize YSNE, but also result in similar or increased yield as conventional practices (SanzCobena et al., 2014b). The inhibitor-based treatments (UI-S and CAN + NI-S) did not significantly affect grain yield or N uptake. Only the NI DMPSA significantly increased biomass yield during 2015 (Table 2). This result is in agreement with Abalos et al. (2014a), who found a better response of inhibitors for biomass than for grain productivity. The results suggest a residual effect of DMPSA, which performed better in the second campaign with regards to biomass production. Consequently, the use of DMPSA was an effective technique for mitigating YSNE in both years, while NBPT only decreased this index significantly during the first year.

Fertigated treatments gave the lowest YSNE, even improving on the efficacy of the inhibitors in both years (with the exception of DMPSA during 2015, which had a similar efficacy as CAN applied by fertigation). The application of water and $\mathrm{N}$ through drip fertigation did not penalize grain yields and even enhanced biomass production in most cases.

The price of inhibitors has been the main barrier for a generalized adoption of these products by farmers (Timilsena et al., 2015). Our results demonstrated that the application of fertilizers through drip-fertigation can improve on the performance of inhibitors for mitigating emissions of $\mathrm{N}$ oxides, without penalizing grain yields. Moreover, the use of an irrigation system with higher water use efficiency (i.e. drip) can result in lower water consumption, thus mitigating $\mathrm{CO}_{2}$ equivalents associated with energy used for pumping (Lal, 2004). There are technical and economic barriers associated with conversion to and maintenance of dripfertigation in maize fields (Sanz-Cobena et al., 2016), particularly in large cropping surfaces. In situations where drip-fertigation is not technically or economically feasible, inhibitors (particularly the NI DMPSA, which resulted in similar YSNE as CAN-D in 2015) could be an economically acceptable alternative (Yang et al., 2016) for improving the sustainability of conventional irrigated maize fields in semi-arid regions. 


\section{Conclusions}

Compared with conventional management of irrigated maize, two strategies arise as the most effective to abate losses of $\mathrm{N}$ oxides GHG emissions while maintaining yield: N supply through dripfertigation (regardless of N Source: U or CAN) and the use of the new nitrification inhibitor DMPSA in sprinkler irrigation. Both management practices were effective in mitigating $\mathrm{N}_{2} \mathrm{O}$ and YSNE losses, thus reducing the global warming potential without penalizing grain yield. Additionally, a positive response of biomass yield and NO losses to both practices was observed, depending on the campaign. Low NO emissions during the first cropping season masked differences between treatments. Inasmuch as the cost of inhibitors represents the main barrier for a widespread adoption at farm level, the installation of drip-fertigation when establishing new maize plantations (when technically viable), is a promising tool for mitigating $\mathrm{N}$ oxides while maintaining crop yields, thus minimizing yield-scaled losses.

We confirmed that the use of NBPT was a useful strategy to reduce $\mathrm{N}_{2} \mathrm{O}$ emissions in both years, while the abatement of YSNE was only significant in one of the two cropping seasons. A significant mitigation of NO losses, compared with urea alone, was only observed in the second campaign. The effect of the $\mathrm{N}$ source on the emissions of $\mathrm{N}$ oxides (i.e. lower emissions in CAN compared with urea) was only found when comparing both fertilizers in sprinkler-irrigated plots and in the campaign with highest $\mathrm{N}$ losses and more favorable soil conditions for nitrification (after $\mathrm{N}$ application). These two strategies (urease inhibitors and substitution of urea by CAN) must be assessed in future studies to confirm their potential to mitigate $\mathrm{N}$ losses without penalizing yields.

\section{Acknowledgements}

The authors are grateful to the Spanish Ministry of Economy and Innovation and the Autonomous Community of Madrid for their economic support through Projects, AGL2012-37815-CO5-01, AGL2015-64582-C3-3-R (MINECO/FEDER) and the Agrisost Project (P2013/ABI-2717). Funding for this research was also provided by EuroChem Agro GmbH and IMIDRA. We offer a special thanks to the field assistants working with us at the "El Encin" field station and technicians (Ana Ros, Paloma Martín, Estrella Revenga, Laura Rubio and Celia Ramírez) at the Department of Chemistry and Food Technology of the ETSIAAB, as well as to the Dr. Mark Theobald for reviewing the English of this manuscript. This work was done in the frame of the Moncloa Campus of International Excellence (UCM-UPM).

\section{References}

Abalos, D., Sanz-Cobena, A., Misselbrook, T., Vallejo, A., 2012. Effectiveness of urease inhibition on the abatement of ammonia, nitrous oxide and nitric oxide emissions in a non-irrigated Mediterranean barley field. Chemosphere 89, 310-318.

Abalos, D., Jeffery, S., Sanz-Cobena, A., Guardia, G., Vallejo, A., 2014a. Meta-analysis of the effect of urease and nitrification inhibitors on crop productivity and nitrogen use efficiency. Agr. Ecosyst. Environ. 189, 136-144.

Abalos, D., Sanchez-Martin, L., Garcia-Torres, L., van Groenigen, J.W., Vallejo, A. 2014b. Management of irrigation frequency and nitrogen fertilization to mitigate GHG and NO emissions from drip-fertigated crops. Sci. Total Environ. 490, 880-888.

Abalos, D., Jeffery, S., Drury, C.F., Wagner-Riddle, C., 2016. Improving fertilizer management in the US and Canada for $\mathrm{N}_{2} \mathrm{O}$ mitigation: understanding potential positive and negative side-effects on corn yields. Agr. Ecosyst. Environ. 221, 214-221

Aguilera, E., Lassaletta, L., Sanz-Cobena, A., Garnier, J., Vallejo, A., 2013. The potential of organic fertilizers and water management to reduce $\mathrm{N}_{2} \mathrm{O}$ emissions in Mediterranean climate cropping systems A review. Agr. Ecosyst. Environ. 164, 32-52

Akiyama, H., Yan, X., Yagi, K., 2010. Evaluation of effectiveness of enhanced-efficiency fertilizers as mitigation options for $\mathrm{N}_{2} \mathrm{O}$ and $\mathrm{NO}$ emissions from agricultural soils: meta-analysis. Glob. Change Biol. 16, 1837-1846.
Allen, R.G., Raes, L.S., Smith, D.M., 1998. Crop Evapotranspiration. Guidelines for Computing Crop Water Requirements. Irrigation and Drainage, Paper 56. FAO, Rome, Italy.

Aronson, E.L., Helliker, B.R., 2010. Methane flux in non-wetland soils in response to nitrogen addition: a meta-analysis. Ecology 91, 3242-3251.

Bittman, S., Dedina, M., Howard, C.M., Oenema, O., Sutton, M.A., 2014. Options for ammonia mitigation: guidance from the UNECE task force on reactive nitrogen. NERC/Centre for Ecol. Hydrol.

Borken, W., Matzner, E., 2009. Reappraisal of drying and wetting effects on C and N mineralization and fluxes in soils. Glob. Change Biol. 15, 808-824.

Cayuela, M.L., Aguilera, E., Sanz-Cobena, A., Adams, D.C., Abalos, D., Barton, L. Ryals, R., Silver, W.L., Alfaro, M.A., Pappa, V.A., Smith, P., Garnier, J., Billen, G., Bouwman, L., Bondeau, A., Lassaletta, A., 2016. Direct nitrous oxide emissions in Mediterranean climate cropping systems: emission factors based on a meta-analysis of available measurement data. Agr. Ecosyst. Environ. (Under review).

Couto, A., Ruiz Padín, A., Reinoso, B., 2013. Comparative yield and water use efficiency of two maize hybrids differing in maturity under solid set sprinkler and two different lateral spacing drip irrigation systems in León, Spain. Agr. Water Manage. 124, 77-84.

Danielson, R.E., Sutherland, P.L., Klute, A., 1986. Porosity. Methods of Soil Analysis. Part 1. Physical and Mineralogical Methods., pp. 443-461.

FAO (Food and Agriculture Organization), 2014. Statistics of Production: Crops, Available online at: http://faostat3. fao.org/browse/Q/QC/E.

Firestone, M.K., Davidson, E.A., 1989. Microbiological basis of $\mathrm{NO}$ and $\mathrm{N}_{2} \mathrm{O}$ production and consumption in soil. In: Andeae, M.O., Schimel, D.S. (Eds.), Exchange of Trace Gases Between Terrestrial Ecosystems and the Atmosphere. Wiley, Chichester, pp. 7-21.

Gilsanz, C., Báez, D., Misselbrook, T.H., Dhanoa, M.S., Cárdenas, L.M., 2016. Development of emission factors and efficiency of two nitrification inhibitors, DCD and DMPP. Agr. Ecosyst. Environ. 216, 1-8.

Guardia, G., Cangani, M.T., Sanz-Cobena, A., Lucas Junior, J., Vallejo, A., 2016. Management of pig manure to mitigate yield-scaled $\mathrm{N}_{2} \mathrm{O}$ losses in an irrigated Mediterranean crop. Agr. Ecosyst. Environ., Under review.

Huang, P., Zhang, J., Zhu, A., Xin, X., Zhang, C., Ma, D., Yang, S., Mirza, Z., Wu, S. 2015. Coupled water and nitrogen $(\mathrm{N})$ management as a key strategy for the mitigation of gaseous N losses in the Huang-Huai-Hai Plain. Biol. Fert. Soils 51, 333-342.

IPCC, 2014. Climate change 2014: synthesis report. In: Pachauri, R.K., Meyer, L.A (Eds.), Contribution of Working Groups I, II and III to the Fifth Assessment Report of the Intergovernmental Panel on Climate Change. IPCC, Geneva, Switzerland (151 pp).

Kennedy, T.L., Suddick, E.C., Six, J., 2013. Reduced nitrous oxide emissions and increased yields in California tomato cropping systems under drip irrigation and fertigation. Agr. Ecosyst. Environ. 170, 16-27.

Kim, D.S., Aneja, V.P., Robarge, W.P., 1994. Characterization of nitrogen oxide fluxes from soil of a fallow field in the central Piedmont of North Carolina. Atmos. Environ. 28, 1129-1137.

Lal, R., 2004. Carbon emission from farm operations. Environ. Int. 30, 981-990. Liang, L.L., Grantz, D.A., Jenerette, G.D., 2015. Multivariate regulation of soil $\mathrm{CO}_{2}$ and $\mathrm{N}_{2} \mathrm{O}$ pulse emissions from agricultural soils. Glob. Change Biol. 22, 1286-1298.

Linn, D.M., Doran, J.W., 1984. Effect of water-filled pore space on carbon dioxide and nitrous oxide production in tilled and nontilled soils. Soil Sci. Soc. Am. J. 48, 1267-1272

Malyan, S.K., Bhatia, A., Kumar, A., Gupta, D.K., Singh, R., Kumar, S.S., Tomer, R., Kumar, O., Jain, N., 2016. Methane production, oxidation and mitigation: a mechanistic understanding and comprehensive evaluation of influencing factors. Sci. Total Environ. 572, 874-896.

Maris, S.C., Teira-Esmatges, M.R., Arbonés, A., Rufat, J., 2015. Effect of irrigation, nitrogen application, and a nitrification inhibitor on nitrous oxide: carbon dioxide and methane emissions from an olive (Olea europaea L.) orchard. Sci. Total Environ. 538, 966-978.

Migliorati, M.D.A., Scheer, C., Grace, P.R., Rowlings, D.W., Bell, M., McGree, J., 2014 Influence of different nitrogen rates and DMPP nitrification inhibitor on annual $\mathrm{N}_{2} \mathrm{O}$ emissions from a subtropical wheat-maize cropping system. Agr. Ecosyst Environ. 186, 33-43.

Myhre, G., Shindell, D., Bréon, F.M., Collins, W., Fuglestvedt, J., Huang, J., Koch, D. Lamarque, J.F., Lee, D., Mendoza, B., Nakajima, T., Robock, A., Stephens, G., Takemura, T., Zhang, H., 2013. Anthropogenic and natural radiative forcing. In: Stocker, T.F., Qin, D., Plattner, G.K., Tignor, M., Allen, S.K., Boschung, J., Nauels, A., Xia, Y., Bex, V., Midgley, P.M. (Eds.), Climate Change 2013: The Physical Science Basis. Contribution of Working Group I to the Fifth Assessment Report of the Intergovernmental Panel on Climate Change. Cambridge University Press, Cambridge, UK and New York, NY, USA, pp. 659-740.

Pilegaard, K., 2013. Processes regulating nitric oxide emissions from soils. Philos. T. R. Soc. B. 368 (1621), 20130126

Qiao, C., Liu, L., Hu, S., Compton, J.E., Greaver, T.L., Li, Q., 2015. How inhibiting nitrification affects nitrogen cycle and reduces environmental impacts of anthropogenic nitrogen input. Glob. Change Biol. 21, 1249-1257.

Quemada, M., Baranski, M., Nobel-de Lange, M.N.J., Vallejo, A., Cooper, J.M., 2013. Meta-analysis of strategies to control nitrate leaching in irrigated agricultural systems and their effects on crop yield. Agr. Ecosyst. Environ. 174, 1-10.

Reeves, S., Wang, W., 2015. Optimum sampling time and frequency for measuring $\mathrm{N}_{2} \mathrm{O}$ emissions from a rain-fed cereal cropping system. Sci. Total Environ. 530, 219-226. 
Rimski-Korsakov, H., Rubio, G., Lavado, R.S., 2012. Fate of the nitrogen from fertilizers in field-grown maize. Nutr. Cycl. Agroecosys. 93, 253-263.

Sánchez-Martín, L., Arce, A., Benito, A., Garcia-Torres, L., Vallejo, A., 2008. Influence of drip and furrow irrigation systems on nitrogen oxide emissions from a horticultural crop. Soil Biol. Biochem. 40, 1698-1706.

Sanchez-Martín, L., Meijide, A., Garcia-Torres, L., Vallejo, A., 2010. Combination of drip irrigation and organic fertilizer for mitigating emissions of nitrogen oxides in semiarid climate. Agr. Ecosyst. Environ. 137 (1), 99-107.

Sanz-Cobena, A., Sánchez-Martín, L., García-Torres, L., Vallejo, A., 2012. Gaseous emissions of $\mathrm{N}_{2} \mathrm{O}$ and $\mathrm{NO}$ and $\mathrm{NO}_{3}{ }^{-}$leaching from urea applied with urease and nitrification inhibitors to a maize (Zea mays) crop. Agr. Ecosyst. Environ. 149, 64-73.

Sanz-Cobena, A., García-Marco, S., Quemada, M., Gabriel, J.L., Almendros, P., Vallejo, A., 2014a. Do cover crops enhance $\mathrm{N}_{2} \mathrm{O}, \mathrm{CO}_{2}$ or $\mathrm{CH}_{4}$ emissions from soil in Mediterranean arable systems? Sci. Total Environ. 466, 164-174 (1998).

Sanz-Cobena, A., Lassaletta, L., Estellés, F., Del Prado, A., Guardia, G., Abalos, D. Aguilera, E., Pardo, G., Vallejo, A., Sutton, M.A., Garnier, J., Billen, G., 2014b. Yield-scaled mitigation of ammonia emission from $\mathrm{N}$ fertilization: the Spanish case. Environ. Res. Lett. 9 (12), 125005

Sanz-Cobena, et al., 2016. Strategies for GHG mitigation in Mediterranean agriculture: a review. Agr. Ecosyst. Environ. (accepted).

Skiba, U., Fowler, D., Smith, K.A., 1997. Nitric oxide emissions from agricultural soils in temperate and tropical climates: sources, controls and mitigation options. Nutr. Cycl. Agroecosys. 48 (1-2), 139-153.

Soil Survey Staff, 1992. Keys to Soil Taxonomy, 6th edn. USDA, Washington.

Tate, K., 2015. Soil methane oxidation and land-use change - from process to mitigation. Soil Biol. Biochem. 80, 260-272.
Timilsena, Y.P., Adhikari, R., Casey, P., Muster, T., Gill, H., Adhikari, B., 2015. Enhanced efficiency fertilisers: a review of formulation and nutrient release patterns. J. Sci. Food Agr. 95, 1131-1142.

Vallejo, A., Meijide, A., Boeckx, P., Arce, A., García-torres, L., Aguado, P.L. Sanchez-Martín, L., 2014. Nitrous oxide and methane emissions from a surface drip-irrigated system combined with fertilizer management. Eur. J. Soil Sci. 65 386-395.

Venterea, R.T., Parkin, T.B., Cardenas, L., Petersen, S.O., Pedersen, A.R., 2012. Data analysis considerations. In: de Klein, C.A.M., Harvey, M.J. (Eds.), Nitrous Oxide Chamber Methodology Guidelines. Global Research Alliance on Agricultural Greenhouse Gases.

Veraart, A.J., Steenbergh, A.K., Ho, A., Kim, S.Y., Bodelier, P.L., 2015. Beyond nitrogen: the importance of phosphorus for $\mathrm{CH}_{4}$ oxidation in soils and sediments. Geoderma 259, 337-346.

Yang, M., Fang, Y., Sun, D., Shi, Y., 2016. Efficiency of two nitrification inhibitors (dicyandiamide and 3, 4-dimethypyrazole phosphate) on soil nitrogen transformations and plant productivity: a meta-analysis. Sci. Rep. 6, 22075.

Zaman, M., Saggar, S., Blennerhassett, J.D., Singh, J., 2009. Effect of urease and nitrification inhibitors on $\mathrm{N}$ transformation gaseous emissions of ammonia an nitrous oxide, pasture yield and $\mathrm{N}$ uptake in grazed pasture system. Soil Biol. Biochem. 41, 1270-1280.

Zhang, Y., Mu, Y., Zhou, Y., Tian, D., Liu, J., Zhang, C., 2016. NO and $\mathrm{N}_{2} \mathrm{O}$ emissions from agricultural fields in the North China Plain: origination and mitigation. Sci. Total Environ. 551, 197-204.

van Groenigen, J.W., Velthof, G.L., Oenema, O., van Groenigen, K.J., van Kessel, C., 2010. Towards an agronomic assessment of $\mathrm{N}_{2} \mathrm{O}$ emissions: a case study for arable crops. Eur. J. Soil Sci. 61, 903-913. 